\title{
ANALISIS KUALITAS BAKTERIOLOGIS AIR MINUM ISI ULANG DI KELURAHAN SEMEMI, KECAMATAN BENOWO
}

\author{
Ria Ayu Dewanti*, Lilis Sulistyorini** \\ *,**Departemen Kesehatan Lingkungan, Fakutas Kesehatan Masyarakat, \\ Universitas Airlangga, Surabaya, Jawa Timur Indonesia \\ Alamat Korespondensi: \\ Ria Ayu Dewanti \\ Email:rhieya_81@gmail.com
}

\begin{abstract}
The high demand for drinking water consumption leading to increase public interest to consuming refilleddrinking water, because it's more practice, hygienic and affordable price. But still many Refilled Drinking Water Depots which not yet fulfilled conditions of drinking water quality which have been specified. This aims of this researchwas to analyze the bacteriological quality of raw water and refilled drinking water in the refilled drinking water depots and the incidence of diarrhea in Sememi village, Benowo district. This research was an analytical survey by cross-sectional design. Interview conducted on 100 respondents who are use bulkdrinking water using simple random sampling. Interviews were also to handlers in refilled drinking water depot. The observation included condition and the type of disinfectant were used, and taking water sample to laboratory for examination. The independent variables were bacteriological quality of refilled drinking water, while the incidence of diarrhea most of the dependent variable. Another variable that also studied including duration of use and period storage of refilled drinking water. For the result, all samples of raw water showed growth of E. coli, after processing 2 depots were not eligible. The prevalence of diarrhea in consumens was $16 \%$. It is concluded that 11 of $16(68.75 \%)$ diarrhea patients are consume eligible drinking water refills. Supervision to depots also important to prevent and reduce the incidence diarrhea from drinking water produced.
\end{abstract}

Keywords: Refilled Drinking Water, Drinking Water Depot, diarrhea, E. coli

\begin{abstract}
ABSTRAK
Tingginya kebutuhan terhadap air minum layak konsumsi menyebabkan meningkatnya minat masyarakat dalam mengonsumsi Air Minum Isi Ulang (AMIU) karena lebih praktis, higienis dan harga yang lebih terjangkau. Namun masih banyak Depot Air Minum Isi Ulang (DAMIU) yang belum memenuhi persyaratan kualitas air minum yang telah ditetapkan. Tujuan penelitian untuk menganalisis kualitas bakteriologis air baku dan air minum isi ulang di depot air minum isi ulang dan kejadian diare di Kelurahan Sememi, Kecamatan Benowo. Penelitian ini merupakan survey analitik dengan rancangan cross sectional. Wawancara dilakukan pada 100 responden yang merupakan pengguna air minum isi ulang menggunakan simple random sampling. Observasi dilakukan untuk mempelajari kondisi dan jenis desinfeksi pada depot air minum isi ulang, dan pemeriksaan bakteriologis laboratorium untuk pemeriksaan sampel air. Variabel yang diteliti yaitu kualitas bakteriologis air minum isi ulang dan kejadian diare. Variabel lain yang juga diteliti diantaranya lama penggunaan air minum isi ulang dan lama penyimpanan air minum isi ulang. Hasil pemeriksaan sampel pada air baku 6 depot, semua sampel menunjukkan adanya pertumbuhan $E$. coli, setelah melalui proses pengolahan 2 depot tidak memenuhi syarat. Insidens kejadian diare pada konsumen yaitu 16\%. Angka kejadian paling tinggi yaitu pada konsumen yang membeli air minum isi ulang pada depot yang tidak memenuhi syarat. Disimpulkan
\end{abstract}


bahwa 11 dari $16(68,75 \%)$ penderita diare mengonsumsi air minum isi ulang tidak memenuhi syarat. Pengawasan kepada depot air minum juga penting untuk mencegah dan mengurangi timbulnya risiko diare dan infeksi saluran pencernaan kesehatan dari air minum isi ulang yang dihasilkan.

Kata kunci: Air Minum Isi Ulang, Depot Air Minum Isi Ulang, diare, E. coli

\section{PENDAHULUAN}

Salah satu kebutuhan utama dalam kehidupan makhluk hidup adalah air. Air diperlukan oleh mahluk hidup untuk digunakan dalam berbagai keperluan seperti mandi, memasak dan mencuci. Berdasarkan perhitungan $\mathrm{WHO}$, kebutuhan air masyarakat di negara berkembang adalah 30-60 liter/ orang/hari, kebutuhan air di negara-negara maju memerlukan 60-120 liter/orang/hari (Suyono dan Budiman, 2010). Kebutuhan air juga semakin bertambah seiring dengan meningkatnya jumlah penduduk. Tingginya tingkat pencemaran air menjadi salah satu masalah dalam pengolahan air. Berbagai macam upaya dilakukan terus menerus untuk memperoleh sumber air yang layak atau memenuhi syarat, khususnya air minum (Radji dkk, 2008).

Tingginya kebutuhan terhadap air minum layak konsumsi menyebabkan meningkatnya minat masyarakat dalam mengonsumsi air minum isi ulang, karena lebih praktis, higienis dan harga yang lebih terjangkau. Kota Surabaya menempati posisi tertinggi di Jawa Timur untuk jumlah pengguna air minum isi ulang (Dinkes Provinsi Jatim, 2014). Berdasarkan Permenkes No. 492 tahun 2010 tentang Persyaratan Kualitas Air minum, air minum harus memenuhi syarat kesehatan yang meliputi persyaratan bakteriologis, fisika, kimia, dan radioaktif untuk menjaga kualitasnya sehingga tidak menimbulkan dampak negatif bagi masyarakat.

Setiap depot air minum wajib menjamin air minum yang dihasilkan memenuhi standar baku mutu atau persyaratan kualitas air minum sesuai ketentuan peraturan perundang-undangan dan memenuhi persyaratan higiene sanitasi dalam pengelolaan air minum. Higiene sanitasi depot air minum yang tidak sesuai dengan ketentuan atau peraturan yang berlaku dapat mengakibatkan kualitas air minum yang dihasilkan tidak memenuhi standar kualitas air minum yang ditentukan. Namun dalam kenyataannya masih banyak Depot Air Minum Isi Ulang (DAMIU) yang belum memenuhi persyaratan kualitas air minum yang telah ditetapkan. Apabila kualitas air minum tidak memenuhi syarat khususnya kualitas bakteriologis akan menimbulkan gangguan kesehatan yaitu timbulnya penyakit seperti diare, kolera, tipoid, hepatitis, disentri dan gastroenteritis (Khoeiriyah dkk, 2013).

Hasil penelitian Wandrivel $\mathrm{dkk}$ (2012) menunjukkan, lima dari sembilan sampel mengandung bakteri Coliform. Tiga dari lima sampel yang mengandung bakteri Coliform tersebut terdapat bakteri Escherichia coli. Salah satu penyakit yang disebabkan oleh air minum isi ulang yang kualitas bakteriologisnya buruk adalah diare akibat adanya bakteri Escerichia coli.

Penyakit diare sampai saat ini masih menjadi masalah di Indonesia karena merupakan penyakit endemis dan juga merupakan penyakit potensial Kejadian Luar Biasa (KLB) yang sering disertai dengan kematian. Kota Surabaya menduduki posisi kedua setelah kabupaten Pamekasan untuk jumlah kasus diare yaitu sebanyak 86.893. Beberapa faktor risiko terjadinya diare adalah higiene personal, kondisi lingkungan, sanitasi dasar, perilaku/kebiasaan individu dalam penyehatan air minum isi ulang. Lama penyimpanan/penggunaan air minum isi ulang juga memengaruhi kualitas bakteriologis air minum isi ulang. Menurut hasil pemeriksaan Galus dkk (2014) jumlah bakteri E. coli pada air minum isi ulang Sumber Depot pada penghuni Kos 
Smart Center Kota Gorontalo pada lama penggunaan 48 Jam dan 72 Jam diketahui bahwa semua sampel mengandung bakteri E. coli yang semakin lama dalam penggunaan air minum isi ulang jumlah bakteri pun meningkat.

Jumlah kasus diare di Kec. Benowo pada tahun 2015 sebanyak 983 kasus (Dinkes Kota Surabaya, 2016). Data dari Profil Kesehatan Kota Surabaya Tahun 2013 menyebutkan $10.648 \quad(65,50 \%)$ keluarga di Kecamatan Benowo tercatat sebagai pengguna atau konsumen air minum isi ulang dari 16.256 keluarga yang diperiksa sumber air minumnya. Pengguna terbanyak di Kecamatan Benowo berada di Kelurahan Sememi dengan jumlah 8850 keluarga (Kelurahan Sememi, 2016). Depot yang berada di kelurahan Sememi tercatat sebanyak 16 depot air minum isi ulang (terbanyak dalam wilayah kecamatan). Di Kelurahan Sememi selama bulan JanuariJuli 2016 ada 392 jiwa yang menderita diare. Di Kelurahan Sememi banyak terdapat kos-kosan yang menggunakan air minum isi ulang sebagai sumber air minum dan usaha kecil makanan yang rata-rata menggunakan air minum isi ulang sebagai air baku untuk proses produksi. Penghuni kos biasanya menyimpan air minum isi ulang untuk beberapa waktu (tidak langsung habis dikonsumsi dalam sehari). Oleh karena itu perlu dilakukan penelitian terkait kualitas bakteriologis air meliputi air baku dan air minum isi ulang di Depot Air Minum Isi Ulang (DAMIU) di Kelurahan Sememi, Kecamatan Benowo.

\section{METODE PENELITIAN}

Penelitian ini merupakan penelitian survey analitik dengan rancangan/desain cross sectional. Penelitian ini dilakukan di Kelurahan Sememi, Kecamatan Benowo pada bulan November sampai Desember 2016. Populasi dalam penelitian adalah konsumen yang merupakan pengguna air minum isi ulang berjumlah 8850 kepala keluarga. Populasi DAMIU yang berada di Kelurahan Sememi berjumlah 16 DAMIU.

Penentuan besar sampel dalam populasi didapatkan dari populasi yang berjumlah 8850 kepala keluarga dengan tingkat signifikansi $(d)=0,1$ sehingga didapatkan sampel berjumlah 100 responden yaitu konsumen pengguna air minum isi ulang di Kelurahan Sememi yang menggunakan air minum isi ulang sebagai sumber air minum. Setelah dilakukan wawancara terhadap 100 responden, didapatkan 6 sampel depot air minum isi ulang yang digunakan oleh responden. Penjamah yaitu operator DAMIU yang melakukan pengoperasian/ proses pengisian air minum isi ulang pada 6 depot air minum isi ulang yang digunakan oleh konsumen tersampling juga menjadi responden dalam penelitian ini.

Selanjutnya, sampel air yaitu sampel air baku dari depot air minum isi ulang (sumber air minum isi ulang yang digunakan oleh 100 responden) di kelurahan Sememi sebelum dan sesudah proses pengolahan sebagai gambaran kualitas bakteriologis air minum isi ulang di depot air minum isi ulang yaitu berjumlah 12 sampel air (6 sampel air baku dan 6 sampel air minum isi ulang). Pengambilan sampel air di 6 depot air minum isi ulang dilaksanakan pada tanggal 14 dan 15 Desember 2016.

Teknik pengambilan sampel menggunakan simple random sampling. Langkah dalam pengambilan sampel yaitu langkah pertama mendaftar nama seluruh populasi yang telah ditetapkan. Langkah kedua yaitu menghitung untuk menentukan sampel, dari perhitungan tersebut didapatkan sampel yang dibutuhkan sesuai perhitungan yang dilakukan yaitu sebanyak 100 orang.

Variabel bebas dalam penelitian ini adalah kualitas bakteriologis air minum isi ulang. Variable terikat dalam penelitian ini adalah kejadian diare, variabel pengganggu adalah lama penggunaan dan lama penyimpanan air minum isi ulang. Data yang digunakan dalam penelitian ini 
menggunakan data primer yang diambil dengan metode wawancara, observasi dan pemeriksaan laboratorium. Wawancara dilakukan dengan panduan kuesioner yang dilakukan secara door to door. Penelitian ini telah mendapatkan persetujuan etik dengan nomor etik 606-KEKP dari FKM UNAIR.

Kemudian observasi dilakukan terhadap kondisi depot air minum isi ulang yang meliputi letak dan kebersihan (lantai, dinding) DAMIU, jenis desinfeksi dan higiene personal penjamah dengan menggunakan lembar observasi. Pemeriksaan laboratorium dilakukan di Laboratorium Kesehatan Lingkungan Poltekkes Kemenkes Surabaya untuk mengetahui keberadaan E. coli dalam air minum isi ulang. Pemeriksaan bakteriologis sampel air, pengambilan sampel dilakukan oleh peneliti dengan langkah menyemprotkan alkohol 70\% pada tangan agar steril, menyiapkan botol pemberat steril yang tutupnya terbungkus kertas aluminium, membuka pembungkus kertas di bagian mulut botol dan menurunkan botol perlahan ke dalam permukaan air (untuk sampel air baku). Pengambilan sampel air minum isi ulang yaitu membuka penutup mulut botol dan mendekatkan mulut botol dengan kran saluran air minum isi ulang, kemudian menyalakan tombol pengisian), menarik tali sambil digulung (untuk sampel air baku), mengisi sampel air pada botol hingga volumenya $\pm 3 / 4$ volume botol, membakar bagian mulut botol, kemudian botol ditutup kembali, memberi label, dan memasukkan pada termos es/colling box dalam suhu $20^{\circ} \mathrm{C}$ selama 1 jam untuk dibawa ke laboratorium.

Data yang telah diperoleh diolah menggunakan komputer dan akan disajikan dalam bentuk deskriptif dalam bentuk tabel dan diagram, menjelaskan bagaimana gambaran kualitas air minum isi ulang di Kelurahan Sememi dan kaitannya dengan kejadian diare dan membandingkan dengan standar baku mutu dalam Permenkes No. 492 tahun 2010.

\section{HASIL}

\section{Gambaran Umum Depot Air Minum Isi Ulang di Kelurahan Sememi}

Depot Air Minum Isi Ulang

Data sekunder yang diperoleh dari Puskesmas Sememi tahun 2016 menyebutkan terdapat 16 depot air minum isi ulang di Kelurahan Sememi. 4 dari 16 DAMIU belum memiliki ijin usaha. Hasil wawancara terhadap 100 responden yang merupakan konsumen air minum isi ulang didapatkan 6 sampel DAMIU yang digunakan oleh responden (konsumen). Kemudian diambil sampel untuk melihat bagaimana kondisi DAMIU, jenis desinfeksi yang digunakan dan dilakukan pemeriksaan laboratorium sebagai gambaran kualitas bakteriologis air minum isi ulang pada DAMIU. Data Kondisi depot air minum isi ulang dapat dilihat pada Tabel 1.

Hasil observasi menunjukkan 3 dari 6 DAMIU menggunakan desinfeksi sinar ultraviolet, 3 DAMIU lainnya menggunakan desinfeksi sinar UV dan ozon. Kondisi dari 6

Tabel 1. Data Kondisi Depot Air Minum Isi Ulang (DAMIU) di Kelurahan Sememi tahun 2016

\begin{tabular}{lccll}
\hline \multirow{2}{*}{ Nama DAMIU } & Desinfeksi & Tandon & \multicolumn{2}{c}{ Kondisi DAMIU } \\
\cline { 5 - 5 } \cline { 4 - 5 } & Galon & Letak & Kebersihan \\
\hline SA & Ultraviolet, ozon & tidak & pinggir jalan raya, dekat pasar & bersih \\
SH & Ultraviolet, ozon & ya, 200 & di dalam teras rumah, halaman luas & bersih \\
TK & Ultarviolet (UV) & tidak & pinggir jalan, dekat pasar & bersih \\
AN & Ultraviolet (UV) & ya, 200 & Pinggir jalan perumahan & kurang bersih \\
DJ & Ultraviolet (UV) & ya, 25 & pinggir jalan, halaman luas & bersih \\
MT & Ultraviolet, ozon & tidak & pinggir jalan raya & bersih \\
\hline
\end{tabular}


Tabel 2. Hasil Pemeriksaan Sampel Air Baku pada DAMIU

\begin{tabular}{ccc}
\hline $\begin{array}{c}\text { Nama } \\
\text { DAMIU }\end{array}$ & $\begin{array}{c}\text { Tanggal } \\
\text { Pengambilan } \\
\text { Sampel }\end{array}$ & $\begin{array}{c}\text { Hasil } \\
\text { Pemeriksaan } \\
\text { E. coli/100 ml }\end{array}$ \\
\hline SA & $14 / 12 / 2016$ & 4,4 \\
SH & $14 / 12 / 2016$ & 5 \\
TK & $14 / 12 / 2016$ & 7,6 \\
AN & $14 / 12 / 2016$ & 2,2 \\
DJ & $15 / 12 / 2016$ & 2 \\
MT & $15 / 12 / 2016$ & 4,4 \\
\hline
\end{tabular}

DAMIU di Kelurahan Sememi cukup baik. Hanya satu DAMIU yang kurang menjaga kebersihan depot. Sebagian besar depot terletak di pinggir jalan perumahan. Ada beberapa depot yang menyimpan air galon sebagai tandon sebelum dijual keesokan harinya kepada pembeli. Depot pertama, ketiga dan keenam tidak menyimpan galon.

Higiene Personal Penjamah

Hasil observasi yang dilakukan pada 6 DAMIU adalah semua penjamah tidak mencuci tangan dengan air mengalir dan sabun setiap melayani konsumen air minum isi ulang (sebelum mengisi air galon).

Depot Air Minum Isi Ulang

Air baku pada DAMIU tersampling di Kelurahan Sememi berasal dari sumber yang sama yaitu mata air Prigen. Air baku diangkut menggunakan mobil tangki aluminium yang didalamnya berlapis stainless steel.

Hasil Pemeriksaan Sampel Air Baku pada depot air minum isi ulang di Kelurahan Sememi.

Tabel 2 menunjukkan hasil pemeriksaan 6 sampel air pada air baku DAMIU menunjukkan bahwa terdapat pertumbuhan E. coli pada semua sampel air baku di DAMIU.

\section{Karakteristik Responden}

Responden dalam penelitian ini adalah konsumen air minum isi ulang yang menggunakan air minum isi ulang sebagai

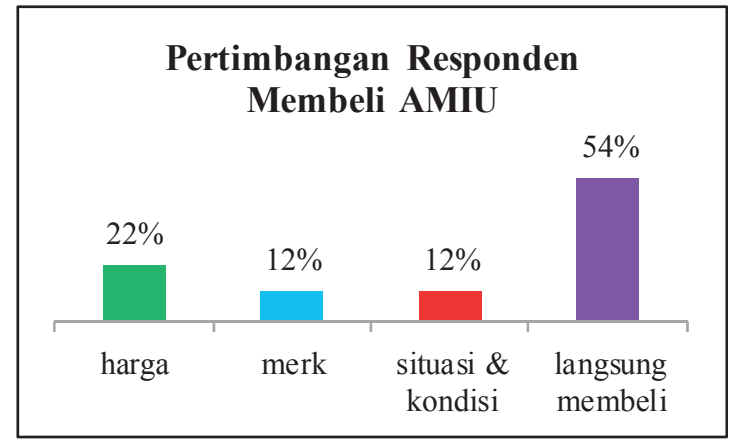

Gambar 1. Diagram Distribusi Responden berdasarkan Pertimbangan Membeli.

air minum sehari-hari yaitu berjumlah 100 orang. $83 \%$ responden berjenis kelamin perempuan dan $17 \%$ berjenis kelamin lakilaki.

Distribusi Responden berdasarkan Pertimbangan Membeli

Gambar 1 menunjukkan bahwa sebagian besar konsumen langsung membeli air minum isi ulang tanpa mempertimbangkan merk, harga, situasi dan kondisi dengan persentase $54 \%$.

Distribusi Responden berdasarkan Jumlah Galon yang Dimiliki

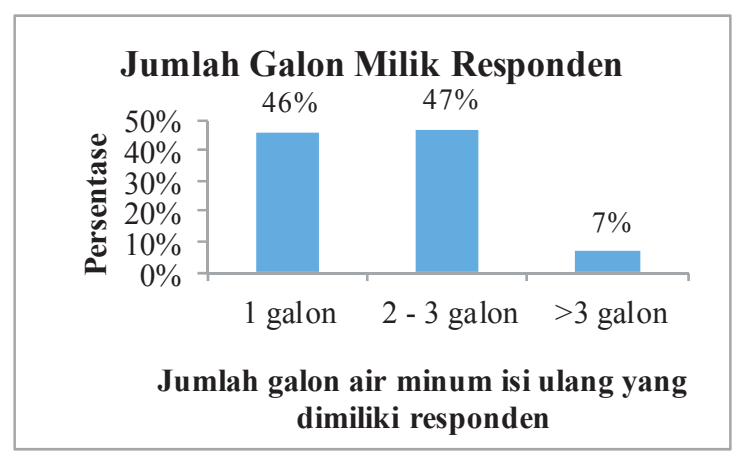

Gambar 2. Diagram Distribusi Responden Berdasarkan Jumlah Galon yang Dimiliki.

Gambar 2 menunjukkan sebagian besar responden rata-rata memiliki 2 hingga 3 galon dalam satu rumah (47\%). 46\% responden hanya memiliki satu (1) galon yang langsung dikonsumsi oleh responden dan keluarga. Ada juga responden yang 


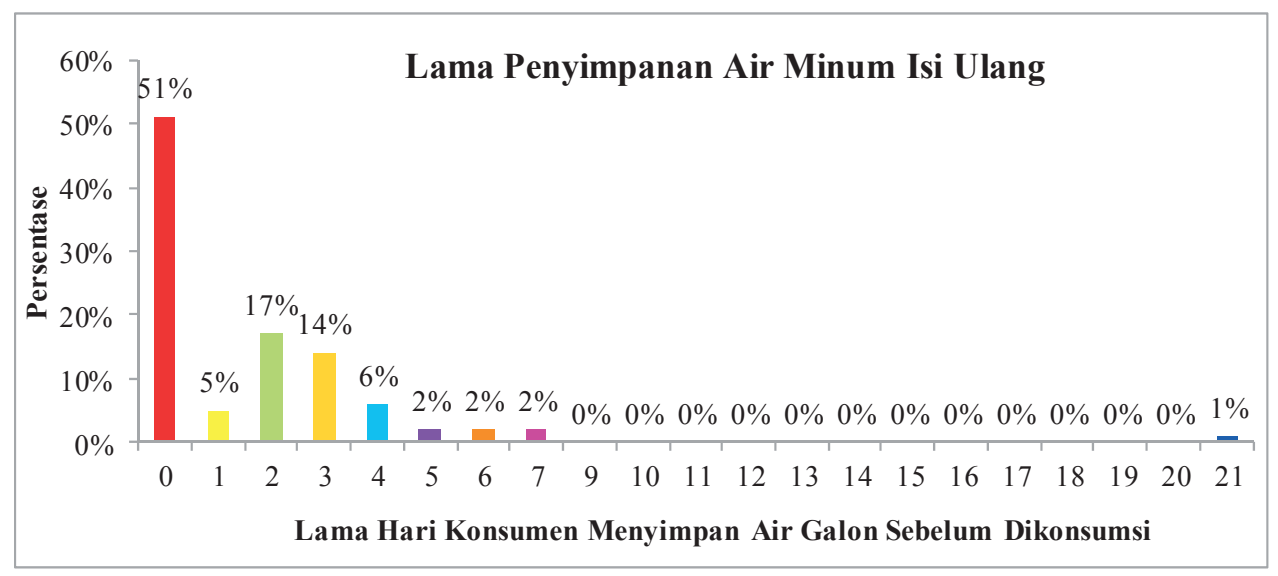

Gambar 3. Ditribusi Responden Berdasarkan Lama Penyimpanan Air Minum Isi Ulang.

memiliki galon penampungan $>3$ dalam satu rumah (7\%). Gambar 3 menunjukkan bahwa sebagian besar responden langsung mengonsumsi air minum isi ulang yang telah dibeli dan tidak menyimpan air minum isi ulang di rumah (51\%). Waktu paling lama responden menyimpan air minum isi ulang adalah selama 21 hari yaitu 1 responden.

Distribusi Responden berdasarkan Lama Penggunaan Air Minum Isi Ulang

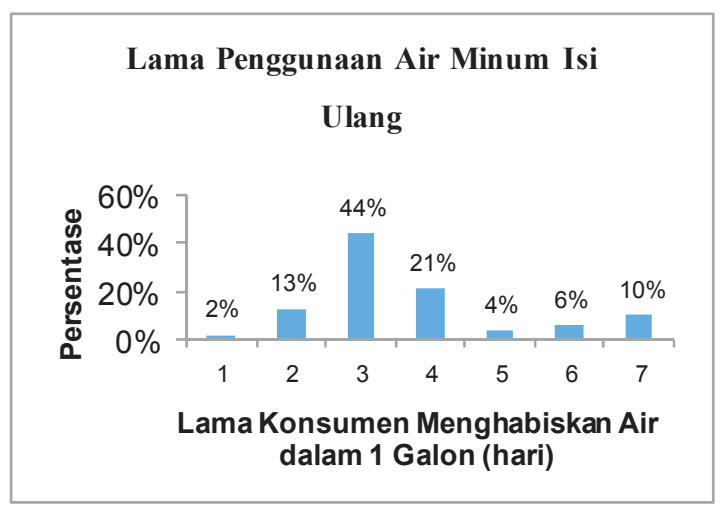

Gambar 4. Diagram Distribusi Responden berdasarkan Lama Penggunaan Air Minum Isi Ulang.

Gambar 4 menunjukkan sebagian besar responden mengonsumsi 1 galon air minum isi ulang dalam waktu 3 hari (44\%). Waktu paling lama responden dalam mengonsumsi air minum isi ulang adalah selama 7 hari untuk 1 galonair minum isi ulang.

\section{Analisis Kualitas Bakteriologis Air Minum Isi Ulang}

Hasil Pemeriksaan Air Minum Isi Ulang

Tabel 3. Hasil Pemeriksaan Sampel Air Minum Isi Ulang

\begin{tabular}{cccc}
\hline $\begin{array}{c}\text { Nama } \\
\text { DAMIU }\end{array}$ & $\begin{array}{c}\text { Tanggal } \\
\text { Pengambilan } \\
\text { Sampel }\end{array}$ & $\begin{array}{c}\text { Hasil } \\
\text { E.coli }\end{array}$ & $\begin{array}{c}\text { Baku Mutu } \\
\text { Permenkes } \\
\mathbf{4 9 2 / 2 0 1 0}\end{array}$ \\
\hline SA & $14 / 12 / 2016$ & $<2^{*}$ & $0 / 100 \mathrm{ml}$ \\
SH & $14 / 12 / 2016$ & $<2^{*}$ & $0 / 100 \mathrm{ml}$ \\
TK & $14 / 12 / 2016$ & 2 & $0 / 100 \mathrm{ml}$ \\
AN & $14 / 12 / 2016$ & 2 & $0 / 100 \mathrm{ml}$ \\
DJ & $15 / 12 / 2016$ & $<2^{*}$ & $0 / 100 \mathrm{ml}$ \\
MT & $15 / 12 / 2016$ & $<2^{*}$ & $0 / 100 \mathrm{ml}$ \\
\hline
\end{tabular}

Keterangan:

$<2 *$ = tidak ada pertumbuhan $E$. coli

Tabel 3 menunjukkan 4 dari 6 sampel air minum isi ulang yang telah melalui proses pengolahan telah memenuhi syarat sesuai baku mutu permenkes No. 492 tahun 2010 yaitu untuk kualitas bakteriologi jumlah E. coli $<0 / 100 \mathrm{ml}$. Namun 2 sampel lainnya masih belum memenuhi baku mutu karena masih terdapat pertumbuhan $E$. coli. 
Distribusi Responden berdasarkan DAMIU

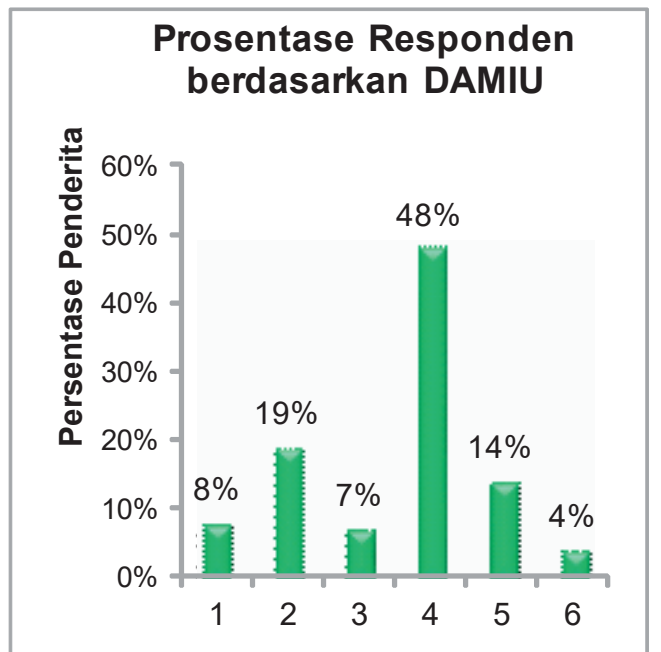

Gambar 5. Diagram Distribusi Responden berdasarkan Depot Air Minum Isi Ulang.

Gambar 5 menunjukkan bahwa sebagian besar responden membeli air minum isi ulang di DAMIU 4 (48\%). 19 responden membeli air minum isi ulang di DAMIU 2. Paling sedikit adalah DAMIU 6 yaitu terdapat 4 responden yang membeli air minum isi ulang pada DAMIU tersebut.

Distribusi Kejadian Diare pada Konsumen Air Minum Isi Ulang

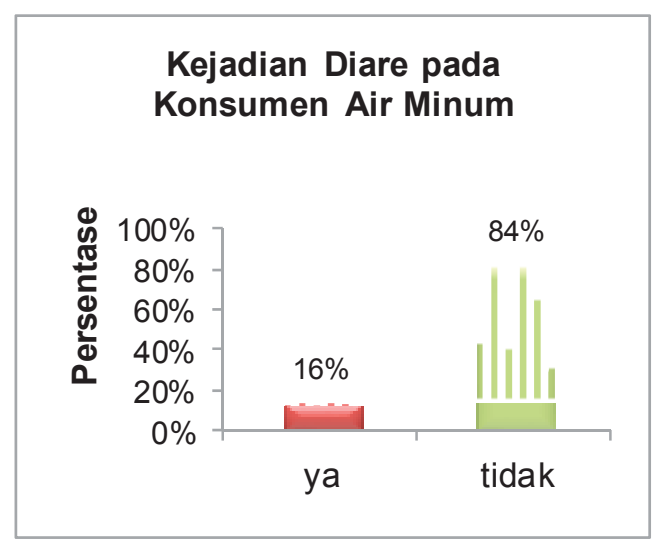

Gambar 6. Diagram Distribusi Kejadian Diare pada Konsumen.

Gambar 6 menunjukkan bahwa 16 dari 100 responden yang mengonsumsi air minum isi ulang menderita diare.
Distribusi Kejadian Diare Pada Konsumen Berdasarkan Depot Air Minum Isi Ulang

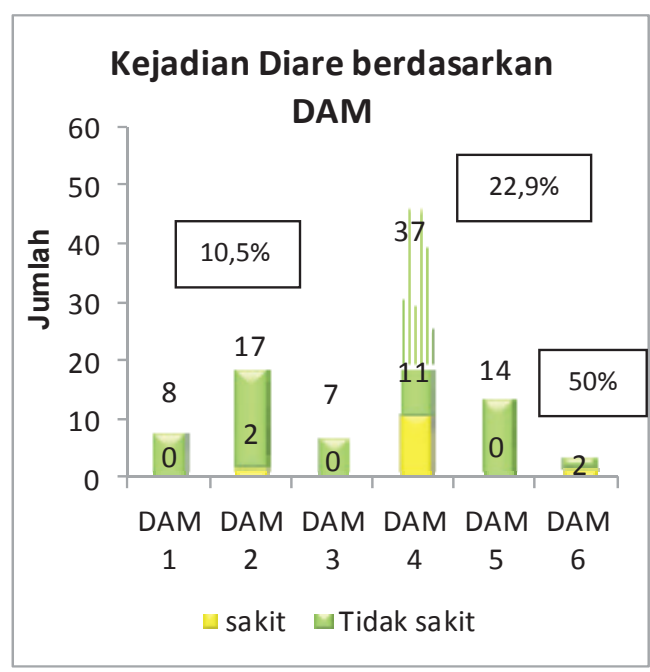

Gambar 7. Diagram Distribusi Kejadian Diare pada Konsumen AMIU Berdasarkan DAMIU.

Gambar 7 menunjukkan bahwa penderita diare terbanyak mengonsumsi air minum isi ulang dari depot 4 . Tercatat 11 konsumen menderita diare dari 48 konsumen yang membeli air di depot 4 .

\section{PEMBAHASAN}

\section{Gambaran Umum Depot Air minum isi ulang di Kelurahan Sememi}

Proses pengolahan air minum isi ulang di depot air minum isi ulang meliputi penampungan air baku, penyaringan/ filterisasi, desinfeksi dan pengisian. Desinfeksi bertujuan untuk membunuh kuman patogen pada air yang akan diolah. Hasil observasi pada 6 DAMIU menunjukkan bahwa 3 dari 6 DAMIU menggunakan desinfeksi sinar ultraviolet, 3 DAMIU lainnya menggunakan desinfeksi sinar UV dan ozon.

Dikenal 2 (dua) cara desinfeksi dalam depot air minum isi ulang yaitu proses desinfeksi dengan menggunakan ozon $\left(\mathrm{O}_{3}\right)$ dan dengan sinar ultraviolet (UV) (Kepmenperindag, 2004). Beberapa faktor yang dapat menyebabkan adanya 
kandungan bakteri dalam air minum isi ulang antara lain terjadi pencemaran pada saat pengolahan atau proses pengolahan (filtrasi dan disinfeksi) yang kurang sempurna (Athena $\mathrm{dkk}, 2004)$. Hal tersebut sesuai dengan penelitian Wulandari (2007) bahwa adanya sistem desinfeksi/sterilisasi seperti ozonisasi, ultraviolet (UV), ozonisasi+UV dan reverse osmosis ( $\mathrm{RO})$ sangat penting untuk membunuh bakteri dalam air minum isi ulang sehingga air minum isi ulang yang dihasilkan memenuhi syarat kesehatan sesuai dengan peraturan yang ditetapkan. Desinfeksi jenis ozon dan sinar UV memiliki kelebihan dan kelemahan masing-masing. Proses ozonasi memerlukan waktu kontak yang singkat namun biayanya relatif mahal baik modal maupun perawatannya. Sinar UV lebih ekonomis dan konsumsi energi yang rendah namun membutuhkan filtrasi awal agar mencapai keefektifannya. Menurut penelitian Wulansarie (2012) degradasi bakteri Escherichia coli ketika disinfeksi dengan menggunakan ozon mencapai 99,39\%. Penggunaan ozon untuk disinfeksi sampel yang mengandung bakteri Escherichia coli cukup signifikan. Kemudian ketika menggunakan sinar UV, degradasi bakteri Escherichia coli mencapai 99,997\%. Artinya disinfeksi menggunakan sinar UV memiliki pengaruh yang lebih signifikan jika dibandingkan dengan disinfeksi menggunakan ozon. Penggabungan antara ozon dan sinar UV, hasil degradasi bakteri Escherichia coli ketika disinfeksi mencapai 99,993\%. Meskipun degradasinya lebih rendah namun jumlah bakteri dari menit ke-3 sampai menit ke-15 untuk disinfeksi dengan ozon dan sinar UV lebih sedikit daripada disinfeksi yang hanya menggunakan sinar UV.

Ada beberapa depot yang menyimpan air galon sebagai tandon sebelum dijual keesokan harinya (hari berikutnya) kepada pembeli. Depot pertama, ketiga dan keenam tidak menyimpan galon, mereka langsung mengisi galon ketika ada pembeli yang datang. Kemudian dari hasil observasi, kondisi dari 6 DAMIU di Kelurahan Sememi cukup baik. Hanya satu DAMIU yang kurang menjaga kebersihan depot. Sebagian besar depot terletak di pinggir jalan perumahan untuk memudahkan akses bagi pembeli. Tempat merupakan salah satu aspek dalam persyaratan hygiene sanitasi depot air minum isi ulang (Permenkes No 43 Tahun 2014). Beberapa point diantaranya lokasi depot air minum isi ulang berada di daerah yang bebas dari pencemaran lingkungan dan penularan penyakit dan bebas dari vektor dan binatang pembawa penyakit seperti lalat, tikus dan kecoa. 2 dari DAMIU terletak di pinggir jalan yang berdampak pada terjadinya pencemaran lingkungan. 3 DAMIU yang berada di pinggir jalan raya memiliki potensi lebih besar terjadi pencemaran lingkungan dari pada DAMIU yang terletak di dalam halaman rumah yang dapat mengurangi terjadinya pencemaran lingkungan. Selain itu 2 depot yang berada di kawasan pasar memungkinkan adanya vektor dan binatang pembawa penyakit seperti lalat sehingga dapat menyebabkan terjadinya kontaminasi dan memengaruhi kualitas air minum isi ulang. higiene sanitasi harus diperhatikan oleh setiap penyelenggara usaha depot air minum isi ulang sebagai upaya untuk mengendalikan faktor risiko terjadinya kontaminasi dari tempat, peralatan dan penjamah terhadap air minum isi ulang agar aman dikonsumsi (Permenkes Nomor 43 tahun 2014).

\section{Higiene Personal Penjamah}

Penjamah merupakan orang yang secara langsung menangani proses pengelolaan dan salah satu aspek dalam penilaian hygiene sanitasi DAMIU. Hasil dari observasi pada 6 DAMIU, semua penjamah tidak mencuci tangan dengan air mengalir dan sabun setiap melayani konsumen AMIU (sebelum mengisi air galon). Mereka berpendapat bahwa mencuci dengan air saja sudah cukup, selain itu sudah ada desinfeksi berupa UV atau ozon sehingga bakteri akan terbunuh dengan desinfeksi tersebut. 
Pada bab II pasal 7 Kepmenperindag 651 tahun 2004 dinyatakan bahwa penjamah harus sehat dan bebas dari penyakit menular serta tidak menjadi pembawa kuman patogen (carrier) dan berperilaku higienis dan saniter setiap melayani konsumen antara lain selalu mencuci tangan dengan sabun dan air yang mengalir setiap melayani konsumen, menggunakan pakaian kerja yang bersih dan rapi, dan tidak merokok setiap melayani konsumen. Berperilaku higienis dan saniter perlu dilakukan setiap melayani konsumen untuk mencegah pencemaran (Permenkes, 2014). Tangan yang tidak bersih dapat menjadi sumber kontaminasi bakteri patogen yang dapat meningkatkan risiko pencemaran (Cahyaningsing dkk, 2009). Bagi pekerja depot air minum isi ulang kebersihan tangan sangat penting. Kebiasaan rajin mencuci tangan sangat membantu dalam pencegahan penularan bakteri dari tangan. Pada prinsipnya pencucian tangan dilakukan setiap saat setelah menyentuh benda-benda yang dapat menjadi sumber kontaminasi atau cemaran (Asfawi, 2004).

Oleh sebab itu depot air minum isi ulang harus menjaga higiene sanitasi agar terhindar dari kontaminasi bakteri. Tempat yang terjamin higiene sanitasinya, tenaga kerja yang berperilaku bersih dan sehat, peralatan yang direkomendasikan aman serta air baku berasal dari sumber air bersih akan menjamin mutu air sehat dan aman (Kepmenkes RI, 2010).

\section{Air Baku Depot Air Minum Isi Ulang}

Hasil observasi yang dilakukan pada 6 depot air minum isi ulang adalah air baku pada depot air minum isi ulang tersampling di Kelurahan Sememi berasal dari sumber yang sama yaitu mata air Prigen. Depot air minum isi ulang di Kelurahan Sememi telah mematuhi peraturan tersebut dengan tidak menggunakan sumber air Perusahaan Daerah Air Minum (PDAM) melainkan menggunakan sumber mata air Prigen sesuai persyaratan Kepmenperindag Nomor 651 Tahun 2004 yang menyatakan bahwa depot air minum isi ulang dilarang mengambil air baku yang berasal dari air PDAM yang ada dalam jaringan distribusi untuk rumah tangga.

Air baku diangkut menggunakan mobil tangki aluminium yang didalamnya berlapis steinless steel. Bahan baku utama yang digunakan adalah air yang diambil dari sumber yang terjamin kualitasnya sesuai Kepmenperindag No. 651/2004. Air baku yang diambil dari mata air yang terbuka dimungkinkan dapat terkontaminasi oleh lingkungan di sekitar (Rahayu dkk, 2008).

Proses pengambilan air baku dari mata air menuju depot air minum isi ulang juga perlu diperhatikan kebersihannya karena proses pengangkutan menggunakan mobil tangki, sehingga memungkinkan air baku dapat tercemar baik dari lingkungan maupun selama dalam perjalanan dan membuat mikroorganisme berkembang. Oleh sebab itu dalam peraturan diatur bahwa transportasi air baku dari lokasi sumber air baku ke depot air minum isi ulang harus menggunakan tangki pengangkut air yang berbahan tara pangan (food grade) dan harus bebas dari bahan-bahan yang dapat mencemari air (Kepmenperindag, 2004).

Hasil pemeriksaan 6 sampel air pada air baku di depot air minum isi ulang di Kelurahan Sememi menunjukkan bahwa terdapat pertumbuhan E. coli pada semua sampel air baku di 6 DAMIU. Hal tersebut kemungkinan dapat terjadi akibat sumber bahan baku telah tercemar oleh bakteri sebelum dilakukan pengolahan.

\section{Karakteristik Responden}

Hasil wawancara terhadap 100 responden, paling banyak berjenis kelamin perempuan (83\%). Sebagian besar konsumen langsung membeli air minum isi ulang tanpa mempertimbangkan merk, harga, situasi dan kondisi dengan persentase 54\%.

Keputusan pembelian konsumen adalah suatu keputusan yang diambil oleh seorang calon pembeli menyangkut kepastian akan membeli atau tidak (Kotler, 2002). Konsumen memutuskan untuk 
langsung membeli air minum isi ulang tanpa memikirkan pertimbangan lain, karena menurut konsumen, harga air minum isi ulang semua sama dijual antara Rp. 4000,hingga Rp. 5000,-. Jenis konsumen ini dinamakan self justiftying customers yaitu pelanggan atau pembeli ketika memiliki buying problem atau mendapatkan masalah, mereka langsung membeli dan menilai barang setelah mereka membelinya (Smith, 1995).

Sebagian besar responden (47\%) ratarata memiliki 2 hingga 3 galon dalam satu rumah. $46 \%$ responden hanya memiliki satu (1) galon yang langsung dikonsumsi oleh responden dan keluarga. Ada juga responden yang memiliki galon penampungan $>3$ dalam satu rumah (7\%) (Gambar 3). Semakin banyak jumlah galon maka semakin lama masa simpan galon sebelum dikonsumsi. Sebagian besar responden mengonsumsi 1 galon air minum isi ulang dalam waktu 3 hari (44\%). Waktu paling lama responden dalam mengonsumsi air minum isi ulang adalah selama 7 hari untuk 1 galon isi ulang (Gambar 4). 51\% responden langsung mengonsumsi air minum isi ulang yang telah dibeli dan tidak menyimpan air minum isi ulang di rumah. Waktu paling lama responden menyimpan air minum isi ulang adalah selama 21 hari yaitu 1 responden (Gambar 5).

Air minum isi ulang harus memenuhi persyaratan fisik, kimia dan bakteriologis agar aman dikonsumsi (Permenkes, 2010). Kualitas air minum isi ulang dapat dipengaruhi oleh lama penggunaan dan lama penyimpanan air minum isi ulang. Air minum isi ulang hanya aman digunakan dalam waktu 24 jam, jika lebih dari 24 jam dapat terjadi perkembangan bakteri $E$. coli yang dapat mengganggu kesehatan. Menurut hasil penelitian Galus dkk (2014) dari 19 sampel air minum isi ulang curah pada lama penggunaan 48 jam, 8 sampel memenuhi syarat yang telah ditetapkan 0 (nol) per $100 \mathrm{ml}$ sampel. Pada lama penggunaan 72 jam semua sampel tidak memenuhi syarat. Menurut penelitian Rahayu A
(2008) dari 30 sampel yang diperiksa semua menunjukkan adanya sejumlah bakteri. Gambaran angka TPC (Total Plate Count) setelah air disimpan dalam dispenser selama 2 hari berkisar antara 2 sampai 98 CFU per milliliter. Setelah penyimpanan 4 hari dalam dispenser didapatkan angka TPC berkisar antara 3 sampai 166 CFU per milliliter. Sejumlah 3 sampel menunjukkan angka TPC diatas $100 \mathrm{CFU} /$ milliliter. Dengan demikian setelah 4 hari penyimpanan dalam dispenser sejumlah 3 sampel tidak memenuhi syarat untuk dikonsumsi. Air yang semakin lama disimpan memungkinkan adanya pertumbuhan mikroorganisme yang akan berkembang menjadi bakteri patogen dan akan menyebabkan kadar zat organik menjadi meningkat (Mukaromah dan Yusrin, 2010).

\section{Analisis Kualitas Bakteriologis Air Minum Isi Ulang}

Air minum isi ulang yang aman bagi kesehatan manusia apabila memenuhi persyaratan fisika, kimia, bakteriologis dan radioaktif sehingga apabila dikonsumsi tidak menimbulkan gangguan kesehatan (Permenkes No 492/Menkes/PER/IV/2010 tentang Persyaratan Kualitas Air Minum). Hasil pemeriksaan 6 sampel pada air minum isi ulang, 4 air minum isi ulang yang telah melalui proses pengolahan telah memenuhi syarat sesuai baku mutu. Baku mutu yang dipersyaratkan adalah $E$. coli $<0 / 100 \mathrm{ml}$. Namum 2 sampel masih belum memenuhi baku mutu karena masih ditemukan adanya bakteri E. coli. Sementara sebagian besar responden (48\%) membeli air minum isi ulang pada DAMIU ke 4 yang hasil pemeriksaannya menunjukkan tidak memenuhi syarat. Hal ini dapat menyebabkan terjadinya penyakit diare.

Hasil wawancara pada 100 responden, terdapat 16 responden yang menderita diare. 11 dari 16 penderita mengonsumsi air minum isi ulang yang berasal dari DAMIU 4 sehingga dimungkinkan responden menderita diare karena kualitas air yang dikonsumsi tidak memenuhi syarat. Kualitas bakteriologis 
air minum isi ulang tidak memenuhi syarat apabila terdapat cemaran bakteri Escherichia coli dalam air minum isi ulang. Hal tersebut menunjukkan bahwa air minum isi ulang tersebut pernah terkontaminasi feses manusia dan mungkin dapat mengandung patogen usus. Kualitas bakteriologis air minum isi ulang yang tidak memenuhi syarat dapat menyebabkan diare (Wandrivel dkk, 2012)

\section{SIMPULAN}

Hasil observasi pada seluruh sampel DAMIU di Kelurahan Sememi menunjukkan semua sampel telah menggunakan sinar ultraviolet maupun ozon sebagai desinfeksi. Kondisi dari 6 DAMIU di Kelurahan Sememi cukup baik. Sebagian besar DAMIU terletak di pinggir jalan raya yang memungkinkan terjadinya pencemaran lingkungan. Hasil higiene personal penjamah di semua DAMIU tidak memenuhi syarat. Penjamah tidak mencuci tangan setiap melayani konsumen. Air baku yang digunakan pada semua DAMIU berasal dari sumber yang sama yaitu mata air Prigen dan diangkut dengan tangki alumunium yang didalamnya berlapis stainless stel sesuai dengan yang dipersyaratkan. Sebagian besar konsumen langsung membeli air minum isi ulang tanpa mempertimbangkan merk, harga, situasi dan kondisi (54 responden). Kualitas air minum isi ulang yang dikonsumsi dapat dipengaruhi oleh lama penggunaan air minum isi ulang dan lama penyimpanan. Hasil pemeriksaan sampel 4 dari 6 air minum isi ulang yang telah melalui proses pengolahan telah memenuhi syarat sesuai baku mutu. 48 responden membeli air minum isi ulang pada DAMIU ke 4 yang hasil pemeriksaannya menunjukkan tidak memenuhi syarat. 11 dari 16 penderita mengonsumsi air minum isi ulang yang berasal dari DAMIU 4 sehingga dimungkinkan responden menderita diare karena kualitas air yang dikonsumsi tidak memenuhi syarat.

Saran yang dapat diberikan yaitu pemberian penyuluhan kepada penjamah/ operator DAMIU tentang higiene sanitasi penjamah dan kepada masyarakat tentang pentingnya higiene personal dan 6 waktu mencuci tangan yang disarankan oleh Permenkes No 3 tahun 2014. Selain itu Puskesmas diharapkan bekerjasama dengan Dinas Kesehatan untuk meningkatkan pengawasan kepada DAMIU dengan tujuan mencegah dan mengurangi timbulnya risiko kesehatan dari air minum isi ulang yang dihasilkan DAMIU.

\section{DAFTAR PUSTAKA}

Asfawi S. 2004. Analisis Faktor yang Berhubungan dengan Kualitas Bakteriologis Air Minum Isi Ulang pada Tingkat Produsen di Kota Semarang Tahun 2004. Skripsi. Universitas Diponegoro. Semarang.

Athena S, Hendro M, Anwar M, Haryono. 2004. Kandungan Bakteri Total Coli dan Escherechia Coli/Fecal Coli Air Minum dari Depot Air Minum Isi Ulang di Jakarta, Tanggerang, dan Bekasi. Jakarta: Balai Penelitian dan Pengembangan Kesehatan Depkes RI. Buletin Penelitian Kesehatan 32(4):136.

Cahyaningsih C, Kushadiwijaya H, Tholib A. 2009. Hubungan Higiene Sanitasi dan Perilaku Penjamah Makanan Dengan Kualitas Bakteriologis Peralatan Makan Pada Warung Makan. Jurnal Berita Kedokteran Masyarakat, [e-journal] 25(4), Desember 2009, 180-188. Tersedia di: http://repository.uinjkt.ac.id/[04 Januari 2017]

Dewanti R.A. 2017. Analisis Kualitas Bakteriologis Air Minum, Personal Hygiene dan Kejadian Diare di Kelurahan Sememi Kecamatan Benowo. Skripsi. Surabaya: Universitas Airlangga.

Dinkes Provinsi Jatim. 2014. Profil Kesehatan Provinsi Jawa Timur Tahun 2013. Surabaya: Dinkes Prov Jatim.

Dinkes Kota Surabaya. 2014. Profil Kesehatan Kota Surabaya Tahun 2013. Surabaya: Dinkes Kota Surabaya.

Dinkes Kota Surabaya. 2016. Profil Kesehatan Kota Surabaya Tahun 2015. Surabaya: Dinkes Kota Surabaya. 
Galus, R., Rama, P., Ramly. 2014. Gambaran Jumlah Bakteri Escherichia coli pada Air Minum Isi Ulang Sumber Depot berdasarkan Lama Penggunaan pada Penghuni Kos Smart Center Kota Gorontalo. KIM Fakultas Ilmu Kesehatan dan Keolahragaan Volume 2 Nomor 2. Universitas Negeri Gorotalo. Tersedia di: http://kim.ung.ac.id/[15 Juli 2016]

Kelurahan Sememi. 2016. Data Monografi Triwulan I. Sememi: Kelurahan Sememi.

Kepmenkes RI. 2010. Pedoman Pelaksanaan Penyelenggaraan Hygiene Sanitasi Depot Air Minum. Kemenkes RI. Jakarta.

Kepmenperindag No. 651 Tahun 2004 tentang Persyaratan Teknis Depot Air Minum dan Perdagangannya. Jakarta: Departemen Perindustrian dan Perdagangan RI.

Khoeriyah A, Anies, Henna R. 2013. Aspek Kualitas Bakteriologi dan Sanitasi Fisik Depot Air Minum Isi Ulang (DAMIU) di Kecamatan Cimareme Kabupaten Bandung Barat. Prosiding Seminar Nasional Pengelolaan Sumber Daya Alam dan Lingkungan. Program Magister Ilmu Lingkungan. Universitas Diponegoro. Tersedia di: https://core.ac.uk/download/ files/379/18605611.pdf [15 Juni 2016]

Kotler P. 2002. Manajemen Pemasaran. Jilid 2. Jakarta: Prenhallindo.

Mukaromah, A. dan Yusrin. 2010. Pengaruh Lama Waktu Simpan Pada Suhu Ruang $\left(27-29^{\circ} \mathrm{C}\right)$ Terhadap Kadar Zat Organik pada Air Minum Isi Ulang. Skripsi. Universitas Muhammadiyah Semarang. Tersedia di: jurnal.unimus.ac.id/index. php/psn12012010/article/view/769/823 [04 Januari 2017]

Permenkes No. 43 Tahun 2014 tentang Hygiene Sanitasi Depot Air Minum. Jakarta: Kemenkes.

Permenkes No. 492 Tahun 2010 tentang Persyaratan Kualitas Air Minum. Jakarta: Menkes.
Radji, M., Heria, Herman. 2008. Pemeriksaan Bakteriologis Air minum isi ulang Isi Ulang di Beberapa Depo Air minum isi ulang Isi Ulang di Daerah Lenteng Agung dan Srengseng Sawah Jakarta Selatan. Majalah Ilmu Kefarmasian, Vol. V, No. 2, Agustus 2008, 101-109. ISSN: 1693-9883.

Rahayu, A. 2008. Deteksi Adanya Bakteri pada Air Minum dalam Kemasan Galon. [e-journal] 2(1). Tersedia di:http://elib. fk.uwks.ac.id [04 Januari 2017]

Rahayu, C.S., Setiani, O., Nurjazuli. 2008. Deteksi Adanya Bakteri pada Air Minum dalam Kemasan Galon. [e-journal] 2(1). Tersedia di:http://elib.fk.uwks.ac.id [04 Januari 2017]

Smith, P. 1995. Marketing Communication Intergrat. Approach $2^{\text {nd }} E d$. Kogan Page, London.

Suyono, Budiman. 2010. Ilmu Kesehatan Masyarakat. Jakarta: EGC.

Wandrivel, R., Netty., Yuniar. 2012. Kualitas Air Minum yang Diproduksi Depot Air Minum Isi Ulang di Kecamatan Bungus Padang Berdasarkan Persyaratan Bakteriologis. Jurnal Kesehatan Andalas, [e-journal] 1(3). Tersedia di http://jurnal. fk.unand. ac.id [15 Juni 2016]

Wulandari, A. 2007. Kualitas Bakteriologis Air minum isi ulang di Wilayah Bogor. Jurnal Kesehatan Masyarakat Nasional Oktober 2007, [e-journal] 2(2) Tersedia di: http://jurnalkesmas. ui.ac.id/kesmas/ article/viewFile/271/271 [08 Desember 2016]

Wulansarie R. 2012. Sinergi Teknologi Ozon dan Sinar UV dalam Penyediaan Air Minum Isi Ulang sebagai Terobosan dalam Pencegahan Penyakit Infeksi Diare di Indonesia. Skripsi. Universitas Indonesia. Tersedia di: http://lib.ui.ac.id/ [04 Januari 2017] 